\title{
The Role of Penicillin Acylase in the Resistance of Gram-Negative Bacteria to Penicillins
}

\author{
BY M. COLE AND R. SUTHERLAND \\ Beecham Research Laboratories, Brockham Park, Betchworth, Surrey
}

(Received 20 August 1965)

\begin{abstract}
SUMMARY
The resistance of 148 clinical isolates of Gram-negative bacteria to ampicillin and benzylpenicillin was determined in serial-dilution sensitivity tests, together with the extent of inactivation of the penicillins, and the production of 6-aminopenicillanic acid (6-APA). Many of the cultures were resistant to the penicillins and inactivated the compounds, but only one culture, a strain of Escherichia coli, showed penicillin acylase activity, as indicated by the production of 6-APA. However, the cultural conditions prevailing in serial-dilution tests, namely, stationary culture at $37^{\circ}$, although favourable for the functioning of penicillin acylases, were shown to be highly unfavourable for production of the enzyme by coliform bacteria.
\end{abstract}

\section{INTRODUCTION}

The resistance of certain Gram-negative bacteria to ampicillin and benzylpenicillin has been shown to be associated with the destruction of the penicillins by the $\beta$-lactamase (penicillinase, Fig. 1) activity of these organisms (Ayliffe, 1963; Percival, Brumfitt \& de Louvois, 1963; Sutherland, 1964). However, the occurrence of penicillin acylase activity, leading to the hydrolysis of penicillins with the production of the relatively inactive 6-aminopenicillanic acid (6-APA) (Fig. 1) has been reported in many species of Gram-negative bacteria (Kaufmann \& Bauer, 1960; Rolinson et al. 1960; Claridge, Gourevitch \& Lein, 1960; Huang, Seto \& Shull, 1963), and resistance to penicillins as a result of penicillin acylase activity has been described by English, McBride \& Huang (1960) and by Holt \& Stewart (1964a). The latter authors reported that $40 \%$ of 310 clinical strains of Escherichia coli examined produced penicillin amidase (penicillin acylase), but the properties of the enzyme extracted from one of these cultures, $E$. coli NCIB 9465, (Holt \& Stewart, $1964 b$ ) differed very markedly from those of the penicillin acylases produced by other strains of $E$. coli (Rolinson et al. 1960; Kaufmann, Bauer \& Offe, 1960; Kaufmann \& Bauer, 1964).

The experiments described here were designed to investigate the occurrence of penicillin acylase activity among Gram-negative bacteria of clinical origin and to ascertain the role of this enzyme in the resistance of bacteria to penicillins. Because optimum cultural conditions for the formation of penicillin acylase by Escherichia coli (Kaufmann \& Bauer, 1964) are different from those prevailing in antibiotic sensitivity tests, a lack of activity in these tests might be due either to intrinsic inability of the organism to form the enzyme or to the cultural conditions being unfavourable for production of penicillin acylase. Accordingly, the Gram-negative 
bacteria used in these experiments were examined for penicillin acylase activity, not only in the serial-dilution tests employed routinely for the determination of bacterial sensitivity to antibiotics, but also in experiments using cultural conditions found to be especially favourable for the formation of penicillin acylase by Entero-

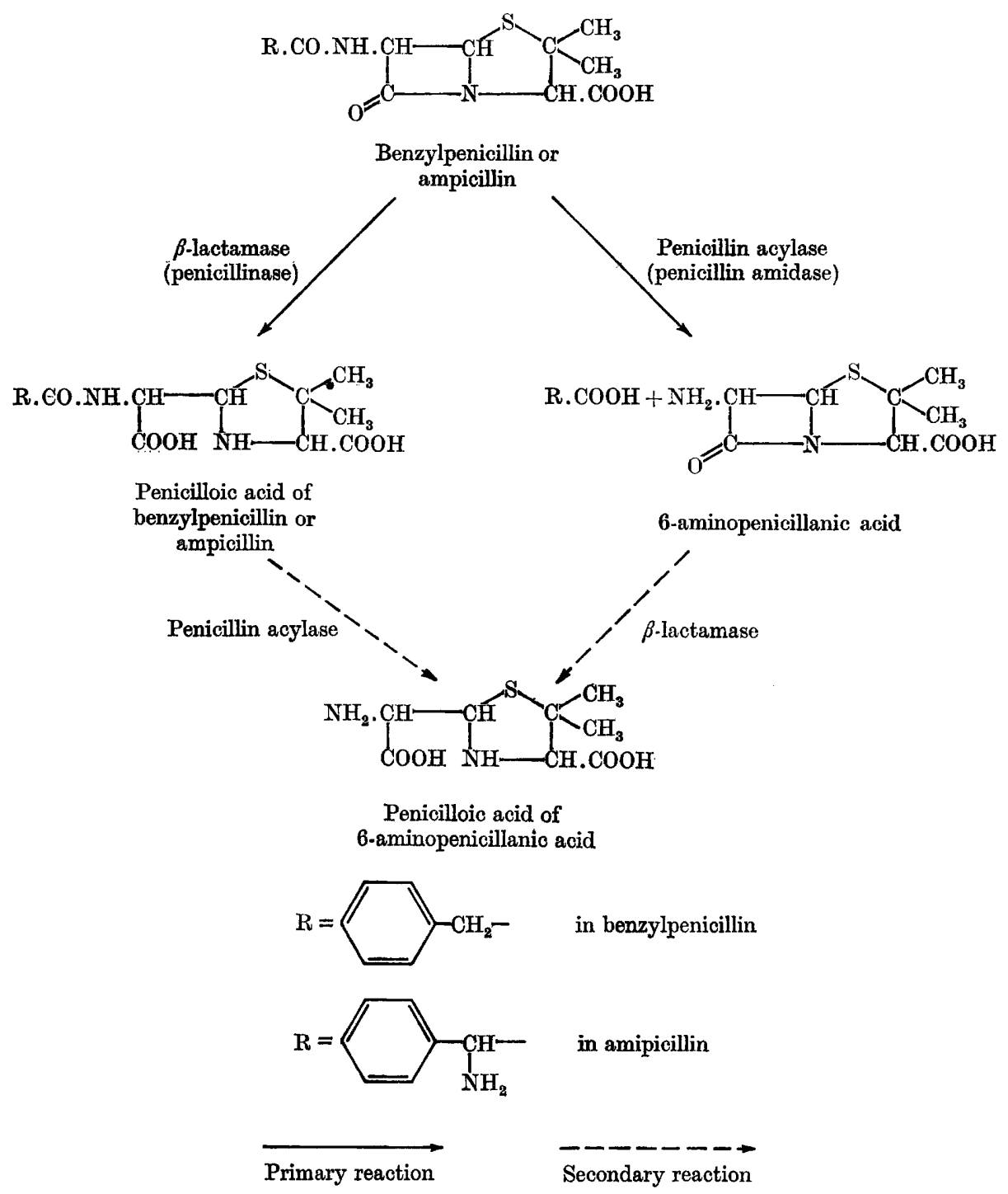

Fig. 1. Degradation of penicillins by Gram-negative bacteria.

bacteriaceae. It was hoped by this means to obtain a true measure of the occurrence of penicillin acylase among Gram-negative bacteria. Three strains of $\boldsymbol{E}$. coli reported by Holt \& Stewart $(1964 a, b)$ to be penicillin acylase-producing cultures were also included in the studies reported here. 


\section{METHODS}

Bacterial cultures. A total of 148 strains of Gram-negative bacteria which were predominantly resistant to ampicillin and benzylpenicillin were obtained from several hospitals. In addition, ten strains of bacteria of non-clinical origin known to produce penicillin acylase were included in these experiments.

Effects of cultural conditions on penicillin acylase formation in Escherichia coli, strain c 975 . Conical flasks $(500 \mathrm{ml}$.) containing $50 \mathrm{ml}$. of medium were inoculated with $0.5 \mathrm{ml}$. of an overnight nutrient broth culture of a clinical strain of $\boldsymbol{E}$. coli, c 975. The cultures were incubated stationary or on a rotary shaker, at $26^{\circ}$ or $37^{\circ}$ (see Table 1 for details). After $18 \mathrm{hr}$ sodium benzylpenicillin was added to all flasks to a final concentration of $1 \mathrm{mg}$. penicillin $/ \mathrm{ml}$. The penicillin was added in $\mathrm{M} / 4$ phosphate buffer ( $\mathrm{pH} \mathrm{8.5)}$ as penicillin acylase is known to be most active under alkaline conditions (Rolinson et al. 1960). All flasks were shaken for $4 \mathrm{hr}$ at $30^{\circ}$ after which samples were assayed for 6-APA as described below. The following media were employed:

(a) Yeatex medium consisting of $2.5 \%$ Yeatex paste (Standard grade, English Grains Ltd., Shobnall Road, Burton-on-Trent, Notts.) in water, adjusted to $\mathbf{p H ~ 7 \cdot 0 .}$

(b) Yeatex medium $+0 \cdot 15 \%$ phenylacetic acid. This acid was dissolved in $\mathrm{NaOH}$ to give a $5 \%$ solution at $\mathrm{pH} 7 \cdot 0$ which was added to the Yeatex medium to the desired concentration, and the whole was adjusted to $\mathrm{pH} 7 \cdot 0$ before sterilization at $15 \mathrm{lb} . / \mathrm{sq}$. in. for $15 \mathrm{~min}$.

(c) Nutrient broth (Oxoid no. 2) adjusted to $\mathrm{pH} 7 \cdot 0$.

(d) Nutrient broth $+0.15 \%$ phenylacetic acid as in $(b)$.

Measurement of antibacterial activity. Minimal inhibitory concentrations of ampicillin and benzylpenicillin required to inhibit growth of the test bacteria were measured by two-fold serial dilution in nutrient broth (Oxoid no. 2). The penicillins were incorporated in graded concentrations in $5 \mathrm{ml}$. volumes of nutrient broth which were inoculated with one drop $(0.03 \mathrm{ml}$.) of an overnight culture of the test organism. Inhibitory concentrations were determined after overnight incubation at $37^{\circ}$.

Measurement of penicillin destruction in penicillin sensitivity tests. The destruction of penicillins in the antibacterial tests described above was estimated by microbiological assay of residual penicillin with an agar diffusion method (Sutherland, 1964). Certain samples were also examined for $\beta$-lactamase activity by chromatographic examination for penicilloic acids.

Penicillin acylase activity in penicillin sensitivity tests. Samples were taken from cultures containing the highest concentration of penicillin allowing growth after overnight incubation and these were examined for 6-APA.

Penicillin acylase in shaken flask cultures. Two $500 \mathrm{ml}$. conical flasks containing $50 \mathrm{ml}$. of a solution consisting of $2.5 \%$ Yeatex paste and sodium phenylacetate at a final concentration equivalent to $0.1 \%$ phenylacetic acid were inoculated with 0.5 ml. of an overnight nutrient broth culture of the test organism. The flasks were shaken on a rotary shaker ( 1 in. throw) at $24^{\circ}$ for $24 \mathrm{hr}$ Ten $\mathrm{ml}$. of a $6 \mathrm{mg} . / \mathrm{ml}$. solution of sodium benzylpenicillin in $\mathrm{m} / 4$ phosphate buffer $(\mathrm{pH} 8 \cdot 5$ ) were added to one of the flasks to give a concentration of $1 \mathrm{mg}$. $/ \mathrm{ml}$. penicillin. A similar quantity of ampicillin was added to the second flask. The flasks were transferred to a rotary shaker and shaken at $30^{\circ}$. After $4 \mathrm{hr} 0.5 \mathrm{ml}$. of $n$-butyl acetate was added to each 
flask and the shaking was continued for a further hour by which time the cultures were non-viable. The flasks were assayed for 6-APA content by paper chromatography as described below. Solutions of benzylpenicillin and ampicillin were also chromatographed to provide standards for the estimation of the amount of residual penicillin in the reaction mixtures.

Analytical methods. Detection and estimation of 6-APA. Filter paper strips, Whatman no. $1,1 \mathrm{~cm}$. wide, were spotted in duplicate with $6 \mu \mathrm{l}$. of the samples under test. The benzylpenicillin reaction mixtures were chromatographed with a butanol +ethanol solvent system ( $n$-butanol+ethanol+water $4+1+5 \mathrm{v} / \mathrm{v}$ top phase). Ampicillin reaction mixtures were chromatographed in a butanol +acetic acid solvent system ( $n$-butanol + acetic acid + water, $12+3+5 \mathrm{v} / \mathrm{v}$ ). In both cases chromatography was carried out overnight at $5^{\circ}$. The chromatograms were dried at $40^{\circ}$ and one of each pair was sprayed with $5 \%$ aqueous sodium bicarbonate, $5 \%$ phenylacetyl chloride in acetone and $5 \%$ aqueous sodium bicarbonate, consecutively, to convert 6-APA into benzylpenicillin (Batchelor, Doyle, Naylor \& Rolinson, 1959). The zones of ampicillin, benzylpenicillin and phenylacetylated 6-APA were located by placing dried chromatograms on nutrient agar seeded with a spore suspension of $B$. subtilis ATcc 6633 and incubated at $37^{\circ}$. The appearance on only the phenylacetylated chromatogram of an antibacterial zone at the $\boldsymbol{R}_{r}$ given below was taken to indicate the presence of 6-APA. Solutions of 6-APA in $\mathrm{m} / 20, \mathrm{pH} \mathrm{7,} \mathrm{phosphate}$ buffer were also chromatographed alongside samples of reaction mixtures so as to provide standards for the estimation of 6-APA. On the phenylacetylated chromatograms a solution of 6-APA $5 \mu \mathrm{g} . / \mathrm{ml}$. yielded an inhibition zone $14-15 \mathrm{~mm}$. wide at an $R_{F}$ of about 0.44 in butanol +acetic acid and $16-18 \mathrm{~mm}$. wide at an $R_{F}$ of about 0.12 in butanol + ethanol. Under these conditions $6-A P A ~ I \mu \mathrm{g} . / \mathrm{ml}$. could be detected. Phenylacetylated chromatograms of the benzylpenicillin and ampicillin solutions showed no zones of 6-APA. Benzylpenicillin had an $\boldsymbol{R}_{\boldsymbol{p}}$ of $0.39 \mathrm{in}$ butanol + ethanol and ampicillin an $\boldsymbol{R}_{F}$ of 0.74 in butanol + acetic acid.

Detection of penicilloic acids. Test samples (6-30 $\mu \mathrm{l}$.), containing about $3 \mu \mathrm{g}$. penicilloic acid were applied to sheets of Whatman No. 1 chromatography paper and $3 \mu \mathrm{g}$. of the penicilloic acids of ampicillin, benzylpenicillin and 6-APA were also treated in the same way, as standards. The penicilloic acids were prepared in two ways. In the first method $5 \mathrm{mg}$. of penicillin or 6-APA in $5 \mathrm{ml}$. of water was treated with $0.75 \mathrm{ml}$. of $5 \mathrm{~N}-\mathrm{NaOH}$ for $30 \mathrm{~min}$. at $37^{\circ}$, after which the solution was neutralized with $0.75 \mathrm{ml}$. of $5 \mathrm{~N}-\mathrm{HCl}$ and the volume made up to $10 \mathrm{ml}$. with water. In the second method $5 \mathrm{mg}$. of penicillin or 6-APA in $5 \mathrm{ml}$. M/20 phosphate buffer (pH 7) was treated for $30 \mathrm{~min}$. at $37^{\circ}$ with $1 \mathrm{ml}$. of the supernatant fluid of a penicillinase ( $\beta$-lactamase)-producing culture of Bacillus cereus, after which the volume was adjusted to $10 \mathrm{ml}$. The chromatograms were developed with a butanol + pyridine solvent ( $n$-butanol + pyridine + water, $1+1+1 \mathrm{v} / \mathrm{v}$ ) overnight at $5^{\circ}$ after which they were dried at $40^{\circ}$ and sprayed with the starch + iodine + acetic acid spray described by Thomas (1961), to reveal white penicilloic acid zones on a dark background. The approximate $\boldsymbol{R}_{F}$ values of the various compounds in the above solvent system were:

$\begin{array}{llll}\text { Benzylpenicillin } & 0.75 & \text { Ampicillin penicilloic acid } & 0.37 \\ \text { Ampicillin } & 0.62 & \text { 6-APA penicilloic acid } & 0.28 \\ \text { Benzylpenicilloic acid } & 0.51 & & \end{array}$




\section{RESULTS}

Factors affecting penicillin acylase formation by Escherichia coli o 975

The results given in Table 1 illustrate the effect of cultural conditions on the formation of penicillin acylase in Escherichia coli c 975, one of the clinical strains of bacteria examined. Under the most favourable conditions, namely, growth at $26^{\circ}$ in a shaken flask of Yeatex medium containing phenylacetic acid, all the available benzylpenicillin was converted to 6-APA. It can be seen that the cultural conditions had a significant effect on the amount of growth, but enzyme formation was not necessarily proportional to bacterial growth. For example, the shaken cultures grown in nutrient broth at $26^{\circ}$ and at $37^{\circ}$ produced similar quantities of bacteria, but the penicillin acylase activity of the culture grown at $26^{\circ}$ was at least a hundredfold greater than that of the culture grown at $37^{\circ}$. Likewise, the growth-promoting effect of phenylacetic acid did not account entirely for the observed increase in enzyme activity.

Table 1. Effect of cultural conditions on the production of penicillin acylase by a clinical isolate of Escherichia coli o 975

E. coli c 975 was grown for $18 \mathrm{hr}$ under the conditions shown below, after which benzylpenicillin to a final concentration of $1 \mathrm{mg}$. $/ \mathrm{ml}$. was added to each flask. The cultures were incubated at $30^{\circ}$ for $4 \mathrm{hr}$, when the concentration of 6-APA was measured.

\begin{tabular}{|c|c|c|c|c|c|}
\hline \multirow[b]{2}{*}{ Basal medium } & \multicolumn{2}{|c|}{ Cultural conditions } & \multirow{2}{*}{$\begin{array}{c}0.15 \% \\
\text { phenylacetic } \\
\text { acid }\end{array}$} & \multirow{2}{*}{$\begin{array}{c}\text { Growth: } \\
\text { dry wt. } \\
\text { bacteria } \\
\text { (mg./ml.) }\end{array}$} & \multirow{2}{*}{$\begin{array}{c}\text { Enzyme } \\
\text { activity } \\
\text { 6-APA } \\
(\mu \mathrm{g} . / \mathrm{ml} .)\end{array}$} \\
\hline & $\begin{array}{l}\text { Tempera- } \\
\text { ture }\end{array}$ & Aeration & & & \\
\hline $2.5 \%$ nutrient broth pH $7 \cdot 0$ & $\mathbf{3} 7^{\circ}$ & Static & Absent & $\mathbf{0} \cdot \mathbf{3 8}$ & Trace \\
\hline & $37^{\circ}$ & Shaken & Absent & $1 \cdot 13$ & Trace \\
\hline & $26^{\circ}$ & Static & Absent & $\mathbf{0} \cdot \mathbf{3 3}$ & 18 \\
\hline & $26^{\circ}$ & Shaken & Absent & $1 \cdot 39$ & 100 \\
\hline & $26^{\circ}$ & Shaken & Present & $\mathbf{2} \cdot \mathbf{1 4}$ & $\mathbf{5 1 5}$ \\
\hline $2.5 \%$ Yeatex pH 7.0 & $\mathbf{2 6}^{\circ}$ & Shaken & Present & $\mathbf{3 \cdot 6}$ & 635 \\
\hline
\end{tabular}

\section{Distribution of minimal inhibitory concentrations}

The organisms tested for sensitivity to ampicillin and benzylpenicillin, together with the respective minimal inhibitory concentrations, are shown in Table 2. Because the organisms used in this work were predominantly resistant to the penicillins the proportion sensitive to the penicillins in these tests was smaller than is typical of strains encountered routinely in clinical practice (Sutherland \& Rolinson, 1964; Sutherland \& Batchelor, 1964).

\section{Penicillin acylase activity in penicillin sensitivity tests}

In the sensitivity tests with 148 clinical cultures of bacteria, 133 strains (90\%) destroyed benzylpenicillin and 91 strains $(61 \%)$ caused some destruction of ampicillin. However, only one culture, Escherichia coli $\mathrm{I} 187$, showed any penicillin acylase in these tests. With this culture a trace of 6 -APA $(<1 \mu \mathrm{g}$. $/ \mathrm{ml}$.) was detected in the test with benzylpenicillin but none was found with ampicillin. The conditions of $\mathrm{pH}$ (alkaline) and temperature $\left(37^{\circ}\right)$ prevailing in these sensitivity tests were favourable for penicillin acylase activity (Rolinson et al. 1960), hence lack of enzyme activity in these tests was due to absence of the enzyme. 


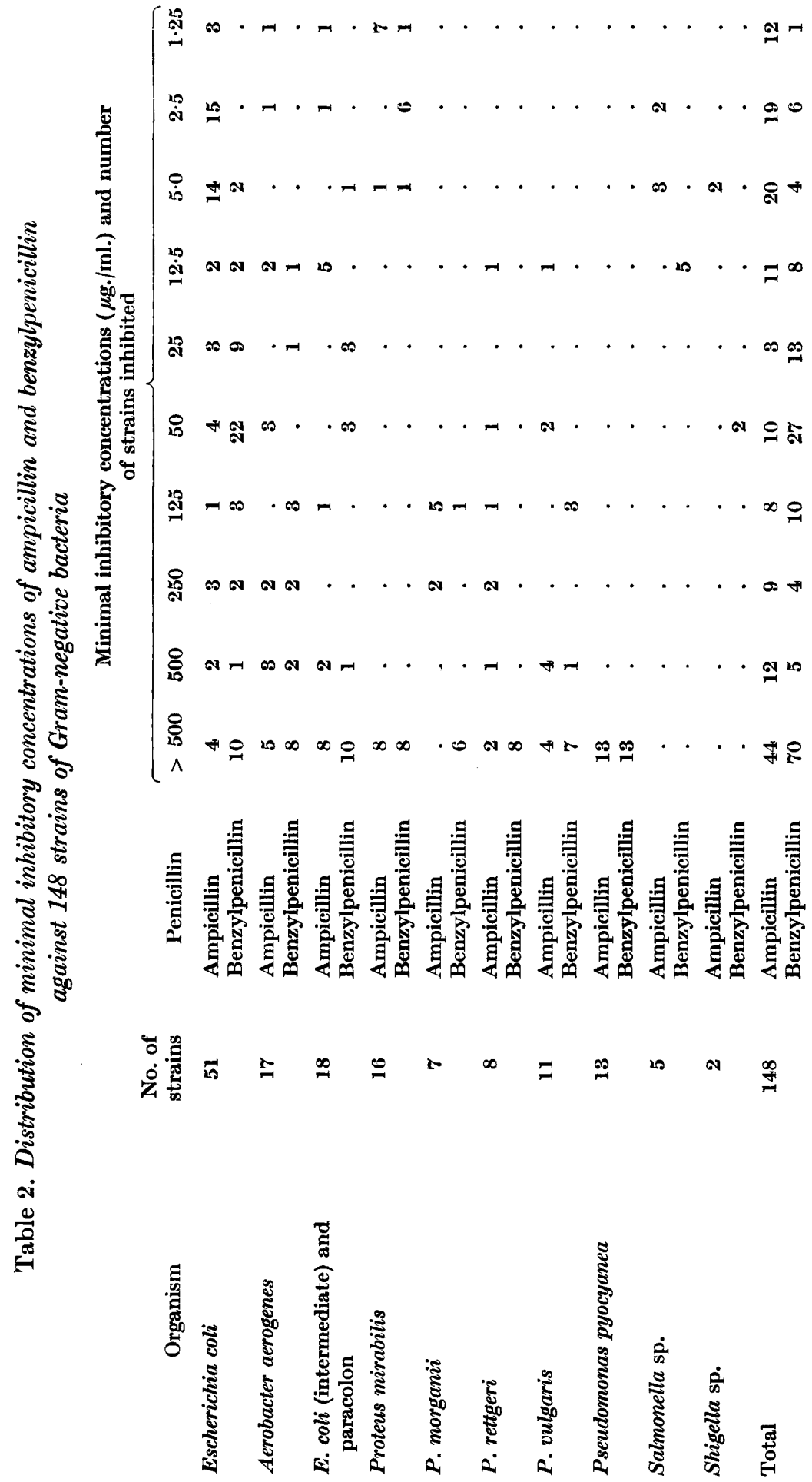




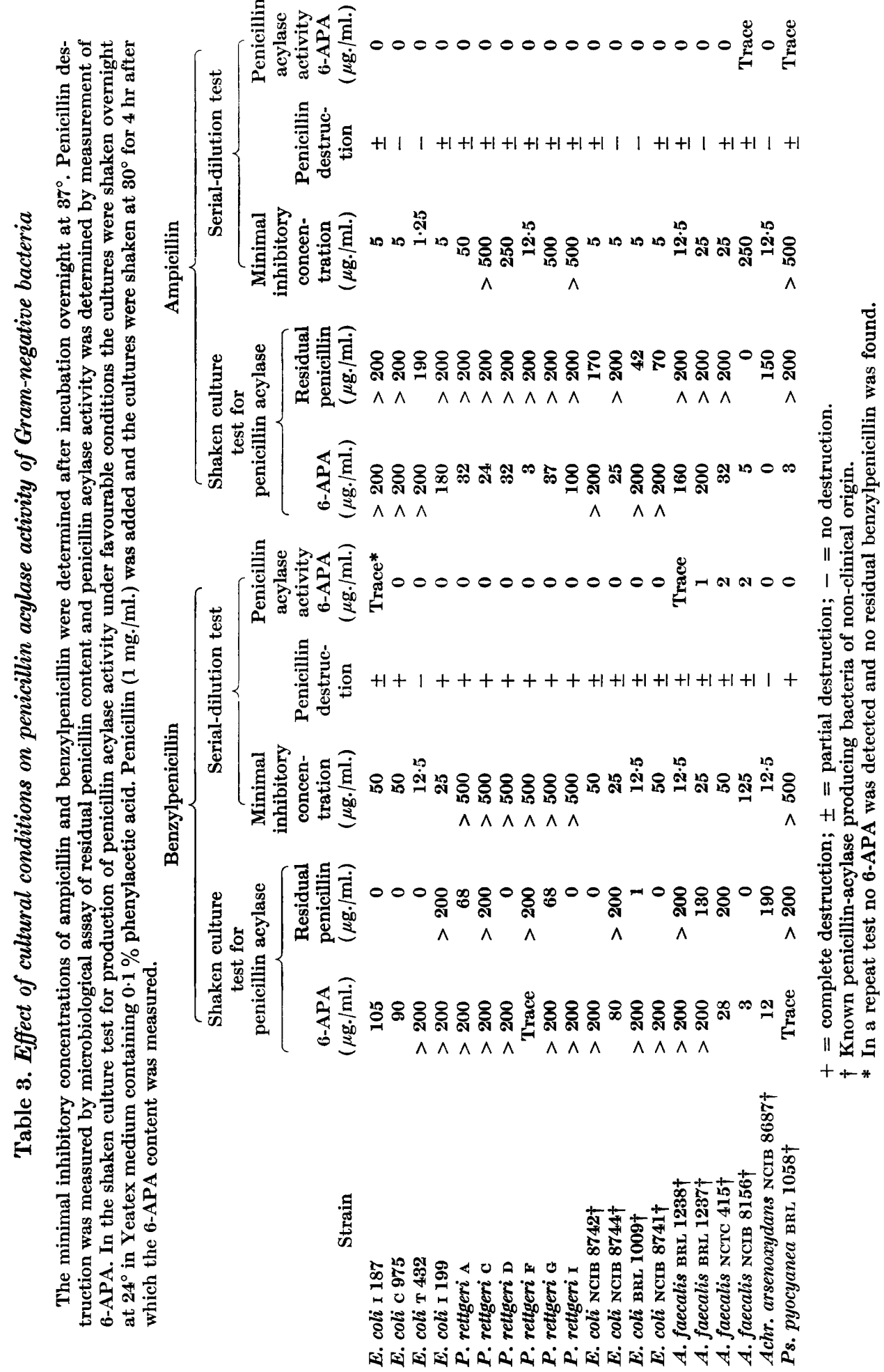




\section{Formation of penicillin acylase by clinical strains of Gram-negative bacteria in shaken flask cultures}

Of the 148 clinical strains of Gram-negative bacteria tested in the shaken flask test with Yeatex medium containing phenylacetic acid, ten strains were found to show penicillin acylase activity (see Table 3). Most of these strains formed large amounts of 6-APA from benzylpenicillin and ampicillin but the ratio of penicillin acylase activities against the two substrates varied from culture to culture. One of the reasons for this is the simultaneous production of penicillin acylase and $\beta$ lactamase in some cultures. For example, with benzylpenicillin as substrate, far less than the theoretical maximum yield of 6-APA (viz. $608 \mu \mathrm{g} . / \mathrm{ml}$.) was obtained from cultures of Escherichia coli I 187 and c 975, although the amount of residual benzylpenicillin in the reaction mixture had fallen to zero, suggesting that some other penicillin-destroying factor, such as $\beta$-lactamase, was operating. However, when ampicillin was used as substrate for these two cultures, the yields of 6-APA were greater and residual ampicillin was present presumably because it was not destroyed by $\beta$-lactamase. These results are consistent with the greater stability of ampicillin to penicillinase ( $\beta$-lactamase) activities of certain Gram-negative bacteria (Ayliffe, 1963; Percival, Brumfitt \& de Louvois, 1963; Smith, 1963; Sutherland, 1964). Where the penicillin acylase activity of cultures was not complicated by the presence of $\beta$-lactamase, as evidenced by the presence of substantial quantities of residual benzylpenicillin, viz. Escherichia coli 199 and Proteus rettgeri c, benzylpenicillin was a better substrate for penicillin acylase than ampicillin. Cultures of $E$. coli $\mathrm{T} 432$ and $\boldsymbol{P}$. rettgeri $\mathrm{A}, \mathrm{D}, \mathrm{G}$ and $\mathrm{I}$, incubated with benzylpenicillin contained more than $200 \mu \mathrm{g} . / \mathrm{ml}$. 6-APA, and low levels of residual penicillin, suggesting that penicillin acylase was the predominant enzyme, although the presence of some $\beta$-lactamase activity cannot be ruled out. Of these cultures, $E$. coli $\mathbf{T} 432$ would appear to be the most active penicillin acylase producer judging by the high yield of 6-APA obtained from ampicillin.

The results in Table 3 also include data obtained with these cultures in the serialdilution sensitivity tests. Although all ten strains produced penicillin acylase in the shaken culture test, this enzyme was absent in serial-dilution tests except in the case of Escherichia coli I 187 for which a trace of 6-APA was detected. These cultures were also examined in the serial-dilution tests for the presence of penicilloic acids. In all cultures where there was significant destruction of the penicillin, the cognate penicilloic acid was detected signifying $\beta$-lactamase activity. In no case was the penicilloic acid of 6-APA observed.

\section{Comparative tests with known penicillin acylase-producing bacteria}

The yields of 6-APA produced by ten strains of saprophytic bacteria in penicillin acylase-producing shaken culture tests are shown in Table3. Comparison of the yields of 6-APA with the amount of residual benzyl penicillin or ampicillin showed that two strains of Alcaligenes faecalis (BRL 1237 and BRL 1238) produced high penicillin acylase activity and in view of the high residual penicillin values, little or no $\beta$ lactamase activity. Three strains of Escherichia coli ( $\mathrm{NCIB} 8742$, NCIB 8741 and BRL 1009) also produced high amounts of penicillin acylase but as the residual benzyl- 


\title{
Penicillin acylase in resistance
}

penicillin values were of a low order it is possible that $\beta$-lactamase was also present. The remaining bacteria demonstrated lower penicillin acylase activity and with A. faecalis NCIB 8156, which produced only 6-APA 3-5 $\mu \mathrm{g} . / \mathrm{ml}$., substantial $\beta$ lactamase activity was present.

In serial-dilution tests with these cultures, penicillin acylase activity was not observed with any of the strains of Escherichia coli. Small amounts of 6-APA were detected with Alcaligenes faecalis in the tests with benzylpenicillin and only one of these strains produced 6-APA in the test with ampicillin. A trace of 6-APA was found in the culture of Pseudomonas pyocyanea BRL 1058 incubated with ampicillin. In no instance did the 6-APA measured account for all of the penicillin destruction observed in the sensitivity tests indicating that $\beta$-lactamase activity was also present.

\section{Destruction of penicillins by Escherichia coli NCIB 9464, ${ }_{N C I B} 9465$ and ${ }_{N C I B} 9466$}

Cultures of Escherichia coli NCIB 9464 NCIB 9465 and NCIB 9466, reported by Holt \& Stewart $(1964 a, b)$ to produce 6-APA from penicillins, were obtained from the National Collection of Industrial Bacteria. All three cultures were resistant to

\section{Table 4. Destruction of penicillins by Escherichia coli NCIB 9464, ${ }_{N C I B} 9465$ and ${ }_{N C I B} 9466$ in sensitivity tests}

\begin{abstract}
Minimal inhibitory concentrations of benzylpenicillin and 6-APA required to inhibit the growth of $E$. coli NCIB 9464, NCIB 9465, and NCIB 9466 for $18 \mathrm{hr}$ at $37^{\circ}$ were determined by serial dilution in nutrient broth. After overnight incubation, residual antibiotic activity was measured by microbiological assay, and 6-APA and penicilloic acid production in the benzylpenicillin sensitivity tests was determined by chromatography
\end{abstract}

Growth and penicillin concentration ( $\mu \mathrm{g} . / \mathrm{ml}$.) after incubation at $37^{\circ}$ for $18 \mathrm{hr}$.

\begin{tabular}{|c|c|c|c|c|c|c|c|c|}
\hline Strain & Penicillin & $500 *$ & ๑50 & 125 & 50 & 25 & $12 \cdot 5$ & $5 \cdot 0$ \\
\hline $\begin{array}{l}\text { Escherichia coli } \\
\text { NCIB } 9464\end{array}$ & $\begin{array}{l}\text { Benzylpenicillin } \\
\text { 6-APA }\end{array}$ & $\begin{array}{c}+ \\
0 \dagger \\
- \\
.\end{array}$ & $\begin{array}{r}+ \\
0 \\
- \\
.\end{array}$ & $\begin{array}{c}+ \\
0 \\
- \\
.\end{array}$ & $\begin{array}{l}+ \\
\dot{+} \\
\mathbf{3 6}\end{array}$ & $\begin{array}{l}+ \\
\dot{1} \\
16\end{array}$ & $\begin{array}{r}+ \\
+ \\
+\end{array}$ & $\begin{array}{l}+ \\
\dot{+} \\
4 \cdot 2\end{array}$ \\
\hline E. coli NCIB 9465 & $\begin{array}{l}\text { Benzylpenicillin } \\
\text { 6-APA }\end{array}$ & $\begin{array}{c}+ \\
0 \dagger \\
- \\
+\end{array}$ & $\begin{array}{c}+ \\
0 \\
- \\
.\end{array}$ & $\begin{array}{c}+ \\
0 \\
- \\
.\end{array}$ & $\begin{array}{l}+ \\
\dot{+} \\
\mathbf{3 3}\end{array}$ & $\begin{array}{l}+ \\
\dot{+} \\
18\end{array}$ & $\begin{array}{l}+ \\
+ \\
+ \\
7 \cdot 6\end{array}$ & $\begin{array}{l}+ \\
+ \\
+ \\
3 \cdot 8\end{array}$ \\
\hline E. coli NсIв 9466 & $\begin{array}{l}\text { Benzylpenicillin } \\
\text { 6-APA }\end{array}$ & $\begin{array}{r}- \\
\mathbf{3 6 0} \\
- \\
.\end{array}$ & $\begin{array}{c}+ \\
0 \\
- \\
.\end{array}$ & $\begin{array}{c}+ \\
\mathbf{0} \\
-\end{array}$ & $\begin{array}{l}+ \\
\dot{+} \\
\mathbf{3 8}\end{array}$ & $\begin{array}{l}+ \\
\dot{+} \\
19\end{array}$ & $\begin{array}{l}+ \\
+ \\
+ \\
6 \cdot 1\end{array}$ & $\begin{array}{c}+ \\
+ \\
+ \\
\mathbf{3 \cdot 8}\end{array}$ \\
\hline
\end{tabular}

benzylpenicillin in serial-dilution tests and brought about complete destruction of the penicillin in these tests (Table 4). Chromatographic examination of these cultures failed to show the presence of 6-APA but, did show benzylpenicilloic acid. 
Destruction of benzylpenicillin in these serial-dilution tests was due therefore to penicillinase ( $\beta$-lactamase) activity. In contrast, 6-APA was highly stable to these cultures of $E$. coli, there being little or no destruction of the compound in the serialdilution tests (Table 4). Moreover, when these strains of $E$. coli were grown under conditions favourable for penicillin acylase production as described in the Methods, no trace of penicillin acylase activity was detected in reactions with benzylpenicillin. However, chromatographic examination of the reaction mixtures showed the presence of benzylpenicilloic acid, indicating $\beta$-lactamase activity.

As the three strains of Escherichia coli failed to show penicillin acylase activity in the tests described above, $E$. coli NCIB 9465 was cultured and tested under the conditions reported by Holt \& Stewart $(1964 b)$. Thus, the organism was grown for $48 \mathrm{hr}$ at $37^{\circ}$ in nutrient broth containing benzylpenicillin $100 \mu \mathrm{g} . / \mathrm{ml}$., but after incubation of the $48-\mathrm{hr}$ old culture with benzylpenicillin at $40^{\circ}, \mathrm{pH} 5 \cdot 5$, no trace of 6-APA was detected. Instead, chromatographic examination of the reaction mixtures at pH 5.5 showed the presence of large amounts of benzylpenicilloic acid and a small amount of benzylpenilloic acid, the the decarboxylation product of benzylpenicilloic acid (Pl. 1). Similarly, a dialysed, freeze-dried specimen of enzyme prepared from $E$. coli NCIB 9465 as described by Holt \& Stewart (1964b) failed to show penicillin acylase activity, but destroyed benzylpenicillin as a result of $\beta$ lactamase activity.

\section{DISCUSSION}

In the experiments described here many of the strains of Gram-negative bacteria used were resistant to ampicillin and benzylpenicillin and were capable of destroying these penicillins in the serial-dilution sensitivity tests, but in only one case, a strain of Escherichia coli I 187, was there any evidence of penicillin acylase activity, namely the production of 6-APA from benzylpenicillin. In this series of tests, therefore, penicillin acylase activity was not a significant factor in the penicillin resistance shown by these cultures. Even with $E$. coli 1 187, in which penicillin acylase was present, penicillin destruction was due primarily to $\beta$-lactamase activity.

It has been our previous experience in this laboratory that production of penicillin acylase by non-clinical strains of Escherichia coli is favoured by low temperature, vigorous aeration and the addition of phenylacetic acid to the medium. The results reported here indicate that these cultural conditions are also favourable for the production of penicillin acylase by bacteria of clinical origin. Even so, out of 148 cultures of clinical bacteria tested, only ten cultures, four strains of $E$. coli and six strains of Proteus rettgeri, converted ampicillin and benzylpenicillin to 6-APA under these conditions. It is evident, therefore, that only a relatively small number of Gram-negative bacteria of clinical origin are capable of producing penicillin acylase. Moreover, these results confirm that the conditions prevailing in sensitivity tests where the bacteria are cultured at alkaline $\mathrm{pH}$ at $37^{\circ}$ in stationary culture, although favourable for the functioning of the enzyme (Rolinson et al. 1960), are most unfavourable for penicillin acylase formation. Hence, most strains of penicillin acylase-producing bacteria are unable to produce the enzyme in serial-dilution tests, but may instead bring about destruction of penicillins by $\beta$-lactamase activity.

The resistance of bacteria to penicillins as a result of penicillin acylase activity 
has been described by English et al. (1960) but few details of experimental conditions or extent of occurrence were given. More recently, Holt \& Stewart $(1964 a, b)$ have reported penicillin acylase activity to play a significant role in bacterial resistance to penicillins and have described the occurrence of penicillin acylase activity in $40 \%$ of clinical strains of coliform bacteria grown in normal nutrient media at $37^{\circ}$. However, we have been unable to demonstrate penicillin acylase activity with cultures of Escherichia coli NCIB 9464, NCIB 9465 and NCIB 9466 reported by Holt $\&$ Stewart $(1964 a, b)$ to be active penicillin acylase-producing cultures. On the contrary, we have found that the inactivation of penicillin by these strains was due solely to $\beta$-lactamase activity with the formation of the cognate penicilloic acid.

The reason for the striking discrepancy between the results reported here with Escherichia coli NCIB 9464, NCIB 9465 and NCIB 9466 and those reported by Holt \& Stewart $(1964 a, b)$ would appear to be due to the fact that Holt \& Stewart classified as penicillin acylase-producing bacteria, cultures which inactivated benzylpenicillin but not 6-APA. However, it is known that 6-APA is usually more stable to the penicillinases ( $\beta$-lactamases) of bacteria than is benzylpenicillin (Percival, Brumfitt \& de Louvois, 1963; Smith \& Hamilton-Miller, 1963). Hence, $\beta$-lactamase producing strains of $\boldsymbol{E}$. coli might well destroy benzylpenicillin much more rapidly than 6-APA and this is the case with $E$. coli NCIB 9464, NCIB 9465 and NCIB 9466. The most satisfactory way of detecting the presence of penicillin acylase is by demonstrating the product of the reaction, 6-APA. This is most conveniently done by detecting the 6-APA on chromatograms of reaction mixtures by making use of the unique property of conversion of 6-APA to a biologically-active substance after treatment with phenylacetyl chloride. The incidence of penicillin acylase among clinical strains of $\boldsymbol{E}$. coli reported by Holt \& Stewart $(1964 a, b)$ must be regarded as being erroneously high.

There seems little doubt that in typical antibiotic sensitivity tests with clinical strains of Gram-negative bacteria, penicillin acylase activity is seldom seen, not only because of the limited number of cultures capable of producing 6-APA from ampicillin or benzylpenicillin, but also because of the unfavourable cultural conditions in serial-dilution tests for the production of penicillin acylase by bacteria. Penicillin acylase activity is thus not a factor normally responsible for resistance of Gram-negative bacteria to ampicillin and benzylpenicillin.

We are grateful to Mrs M. V. Hart and Mrs E. Fairclough for skilled technical assistance and to Dr G. N. Rolinson for helpful advice and criticism.

\section{REFERENCES}

Ayuffe, G. A. J. (1963). Ampicillin inactivation and sensitivity of coliform bacilli. J. gen. Microbiol. 30, 339.

Batchelor, F. R., Doyle, F. P., Nayler, J. H. C. \& Rolinson, G. N. (1959). Synthesis of penicillin: 6-Aminopenicillanic acid in penicillin fermentations. Nature, Lond. 183, 257.

Claridge, C. A., Gourevitch, A. \& Lein, J. (1960). Bacterial penicillin amidase. Nature, Lond. 187, 237.

English, A. R., McBride, T. J. \& Huang, H. T. (1960). Microbial resistance to penicillins as related to penicillinase or penicillin acylase activity. Proc. Soc. exp. Biol. Med. 104, 547. 
Holt, R. J. \& Stewart, G. T. (1964 $\alpha$ ). Production of amidase and $\beta$-lactamase by bacteria. J. gen. Microbiol. 36, 203.

Holt, R. J. \& Stewart, G. T. (1964b). Penicillin amidase from coliforms: its extraction and some characteristics. Nature, Lond. 201, 824.

Huang, H. T., Seto, T. A. \& Shull, G. M. (1963). Distribution and substrate specificity of benzylpenicillin acylase. Appl. Microbiol. 11, 1.

Kaufmann, W. \& Bauer, K. (1960). Enzymatische Spaltung und Resynthese von Penicillin. Naturwiss. 47, 474.

KaUfmanN, W. \& BaUER, K. (1964). The production of penicillin amidase by Escherichia coli Atcc 9637. J. gen. Microbiol. 35, iv.

KaUfmanN, W., BaUER, K. \& OFFe, A. (1960). Enzymatic cleavage and resynthesis of penicillins. Antimicrobial Agents Annual, p. 1. New York: Plenum Press.

Percival, A., Brumfitt, W. \& De Louvois, J. (1963). The role of penicillinase in determining natural and acquired resistance of Gram-negative bacteria to penicillins. J. gen. Microbiol. 32, 77.

Rolinson, G. N., Batchelor, F. R., Butterworth, D., Cameron-Wood, J., Cole, M., Eustace, G. C., Hart, M. V., Richards, M. \& Chain, E. B. (1960). Formation of 6aminopenicillanic acid from penicillin by enzymatic hydrolysis. Nature, Lond. $187,236$.

SмITH, J. T. (1963). Penicillinase and ampicillin resistance in a strain of Escherichia coli. J. gen. Microbiol. 30, 299.

Smith, J. T. \& Hamilon-Miller, J. M. T. (1963). Differences between penicillinases from Gram-positive bacteria and Gram-negative bacteria. Nature, Lond. 197, 976.

SutherLAND, R. (1964). The nature of the insensitivity of Gram-negative bacteria towards penicillins. J. gen. Microbiol. 34, 85.

Sutherland, R. \& Batchelor, F. R. (1964). Synergistic activity of penicillins against penicillinase-producing Gram-negative bacilli. Nature, Lond. 201, 868.

Sutherland, R. \& Rolinson, G. N. (1964). Activity of ampicillin in vitro compared with other antibiotics. J. clin. Path. 17, 461.

Thомas, R. (1961). Colorimetric detection of penicillins and cephalosporins on paper. Nature, Lond. 191, 1161.

\section{EXPLANATION OF PLATE}

Chromatogram showing the degradation of benzylpenicillin by Escherichia coli $\mathrm{NCIB} 94.65$

Chromatography system: $n$-butanol + pyridine + water, $1+1+1 \mathrm{v} / \mathrm{v}$. Descending. Whatman No. 1 . Run overnight at $5^{\circ}$. Starch + iodine spray. Samples 1-5 applied at two spots/origin, i.e. 12-16 $\mu$ l. Reaction mixtures 1-5 consisted of 1 vol. of sodium benzylpenicillin $3000 \mu \mathrm{g}$. $/ \mathrm{ml}$. in $0.2 \mathrm{M}$-acetate buffer (pH 5.5) plus 5 vol. of one of the following, adjusted to $\mathrm{pH} 5.5$ and incubated for $5 \mathrm{hr}$ at $37^{\circ}$.

1. 40 -hr culture of $\mathrm{NCIB} 9465$ grown statically at $37^{\circ}$ in nutrient broth containing benzylpenicillin. $100 \mu \mathrm{g} . / \mathrm{ml}$.

2. E. coli centrifuged from 1 vol. of above culture and resuspended in 1 vol. of $0.2 \mathrm{M}$-acetate buffer (pH 5.5).

3. Filtrate obtained after centrifuging and membrane filtering above culture.

4. Freeze-dried material prepared as in 3 and reconstituted at double original concentration.

5. 0.2 M-acetate buffer ( $\mathrm{pH} \mathrm{5.5).}$

6. Benzylpenicilloic acid $500 \mu \mathrm{g}$. $/ \mathrm{ml}$. prepared by treatment of benzylpenicillin with $\beta$-lactamase obtained from $B$. cereus (one spot/origin).

I = benzylpenicillin, II, = benzylpenilloic acid, III, = benzylpenicilloic acid.

Butanol + ethanol + water chromotograms of reaction mixtures 1-5 did not reveal any 6-APA after phenylacetylation and contacting with agar seeded with $B$. subtilis. A 6-APA zone was detected for a $5 \mu \mathrm{g} . / \mathrm{ml}$. 6-APA solution. 